\title{
Paleobiological Perspectives on the Early Upper Paleolithic Human Transition in the Northwestern old World
}

Perspectives paléobiologiques de la transition populationnelle au début du Paléolithique supérieur en Europe et Asie de l'Ouest

\section{Erik Trinkaus}

\section{OpenEdition \\ Journals}

Electronic version

URL: https://journals.openedition.org/bmsap/6281

DOI: $10.4000 /$ bmsap.6281

ISSN: $1777-5469$

Publisher

Société d'Anthropologie de Paris

Printed version

Date of publication: 30 November 2001

ISSN: 0037-8984

\section{Electronic reference}

Erik Trinkaus, "Paleobiological Perspectives on the Early Upper Paleolithic Human Transition in the Northwestern Old World", Bulletins et mémoires de la Société d'Anthropologie de Paris [Online], 13 (3-4) I 2001, Online since 16 September 2009, connection on 01 June 2021. URL: http:// journals.openedition.org/bmsap/6281 ; DOl: https://doi.org/10.4000/bmsap.6281

\section{(c) $(1) \odot$}

Les contenus des Bulletins et mémoires de la Société d'Anthropologie de Paris sont mis à disposition selon les termes de la licence Creative Commons Attribution-NonCommercial-NoDerivatives 4.0 International License. 


\title{
PALEOBIOLOGICAL PERSPECTIVES ON THE EARLY UPPER PALEOLITHIC HUMAN TRANSITION IN THE NORTHWESTERN OLD WORLD 1 PERSPECTIVES PALÉOBIOLOGIQUES DE LA TRANSITION POPULATIONNELLE AU DÉBUT DU PALÉOLITHIQUE SUPÉRIEUR EN EUROPE ET ASIE DE L'OUEST
}

\author{
Erik TRINKAUS 2
}

\begin{abstract}
The emerging consensus that the emergence of modern humans in the northwestern Old World involved temporally and geographically varying degrees of admixture between Neandertals and early modern humans within the early Upper Paleolithic provides the framework for assessing the complex mosaic of biobehavioral changes which took place across the transition. Despite a series of paleobiological similarities involving cognitive, masticatory and locomotor behaviors, as well as temporal and cultural overlap between the two groups, there remain contrasts in the anterior dentition, the upper limb, femoral structural patterns, stress levels, demographic profiles and stable isotopes. These changes reflect principally the improvements in technology and subsistence of the earlier Upper Paleolithic. Moreover, there are indications that the biobehavioral shift started within the initial Upper Paleolithic Neandertals.
\end{abstract}

Keywords: transition, Middle Paleolithic, Upper Paleolithic, Neandertal, anatomically modern human, behavior, paleobiology.

1. I first encountered Bernard Vandermeersch in 1973, in his laboratory at Jussieu, while I was a graduate student working on Neandertal limb bones and he was a junior faculty member working principally on the Qafzeh human remains. It was a time when our perceptions of Late Pleistocene human evolution were in flux and a group of young human paleontologists were coming to terms with who the Neandertals and early modern humans really were. In the almost three decades since then, the world of Late Pleistocene human paleontology has changed dramatically, from a quaint enterprise to one which has captured the attention of professional and public audiences. It has been a pleasure to ride the roller coaster of those years with Bernard, agreeing and disagreeing along the way, participating in the formulation what we believe (in our naiveté) is an emerging consensus. Without his seminal work at Qafzeh, Saint-Césaire and elsewhere, a new consensus would not have been possible.

2. Department of Anthropology, Campus Box 1114, Washington University, St. Louis, MO 63130 U.S.A, U.M.R. 5809 du C.N.R.S., Laboratoire d'Anthropologie des Populations du Passé, Université de Bordeaux 1, Avenue des Facultés, 33405 Talence, France, e-mail: trinkaus@artsci.wustl.edu 


\begin{abstract}
RÉSUMÉ
Le consensus selon lequel l'expansion des Hommes modernes en Europe et Asia de l'ouest au début du Paléolithique supérieur a nécessité des degrés variables, chronologiquement et géographiquement, de métissage entre les Néandertaliens et ces Hommes modernes, fournit un cadre nouveau pour évaluer la mosä̈que des changements bio-comportementaux qui eurent lieu durant cette période. En dépit d'une série de similitudes paléo-biologiques concernant les capacités cognitives, le système masticateur et la locomotion, et également d'un chevauchement chronologique entre ces deux groupes et de pratiques culturelles voisines, il existe des différences au niveau de la dentition antérieure, du membre supérieur, de l'architecture fémorale, des stresses, des profils démographiques et des isotopes stables. Elles reflètent principalement les améliorations des stratégies de subsistance et de la maîtrise technologique au début du Paléolithique supérieur. Mais, des données prouvent aussi que ces changements bio-comportementaux ont débuté avec les derniers Néandertaliens au début du Paléolithique supérieur.
\end{abstract}

Mots-clés : transition, Paléolithique moyen, Paléolithique supérieur, Néandertalien, homme anatomiquement moderne, comportement, paléobiologie.

\section{INTRODUCTION}

Human paleontological research during recent years has been focused principally on the phylogenetic emergence of early modern humans and the associated extinction of the Neandertals of the northwestern Old World. Through a decade and a half of debate involving the human fossil record, recent human and Neandertal molecular biology, geochronological frameworks, and aspects of the Paleolithic archeological record, a consensus is emerging regarding the phylogenetic processes involved. It is becoming increasingly apparent that the earliest modern humans emerged sometime in the late Middle Pleistocene [oxygen isotope stage (OIS) 6] in Africa (although the location and geographical range of the ancestral population remains uncertain), they spread temporarily into the Near East during OIS 5, remained within Africa during OIS 4, and then during OIS 3 dispersed increasingly across the remainder of the Old World. Most human paleontologists directly involved in this issue agree that, as early modern humans spread across Eurasia (and the remainder of Africa) during OIS 3, they variably replaced or absorbed local populations of late archaic humans (including the Neandertals of the northwestern Old World) to produce the subsequent regional populations of early modern humans. The debate has therefore shifted from one of "replacement" versus "continuity with gene flow" to one concerned with the regional presence or absence of admixture and with the former its degree (from trivial to complete population mixing).

With respect to the Neandertals of the northwestern Old World, forever a focus of the modern human origins debate, human paleontologists either actively argue for some degree of admixture between Neandertals and early modern humans (e.g., Smith and 
Trinkaus, 1991; Frayer, 1993; Smith, 1994; Duarte et al., 1999; Bräuer, 2001; Wolpoff et al., 2001) or admit the possibility of such genetic combinations between the groups (e.g., Hublin, 2000; Stringer, 1994; Vandermeersch, 1995). And increasingly, human population geneticists agree that the recent and past human molecular records are fully compatible with some degree of admixture between these two groups (e.g., Nordborg, 1998; Jorde et al., 1998; Wall, 2000; Relethford, 2001).

It has also become fully established that the initial appearance of modern humans within Africa (and by extension the Levant) occurred within a Middle Paleolithic/Middle Stone Age context, whereas the subsequent spread of early modern humans and the disappearance/absorption of late archaic humans occurred within the early Upper Paleolithic. Not only are we dealing with two separate evolutionary events (or periods), but they occurred within two contrasting techno-cultural contexts. Moreover, the evidence for admixture as early modern humans spread across Europe means that we are dealing with a complex and dynamic human evolutionary transition, not merely a process of one group being replaced by another.

From this emerging synthesis, it has become increasingly feasible to focus in on the processes involved, particularly biobehavioral aspects of the human biological transition which occurred within the early Upper Paleolithic of Europe and western Asia. However, given the dearth of Neandertal remains associated with the initial Upper Paleolithic (those of Saint-Césaire, Vindija $\mathrm{G}_{1}$ and Arcy-Renne) and of early modern humans from the Aurignacian (all later than 33 Ka B.P.), it is necessary to compare Middle Paleolithic Neandertals to earlier Upper Paleolithic (principally Gravettian) humans. In these comparisons, one must bear in mind that the evolutionary transition was between the contemporaneous humans between ca. 33 and 28 Ka B.P., and that the earlier and later groups provide the outgroups for the transition.

\section{SAMPLES AND APPROACHES}

The following discussion is a summary of ongoing research on the paleobiological similarities and contrasts between late archaic and early modern humans in the northwestern Old World. As such, the comparisons here are principally between Middle Paleolithic Neandertals of Europe and the Near East on the one hand and earlier Upper Paleolithic early modern humans of the same region on the other hand. Discussed when possible are the European initial Upper Paleolithic Neandertal specimens. The first sample is limited to specimens from OIS 4 and 3, whereas the second sample includes those from the Aurignacian to the last glacial maximum, ca. 32 to 19 Ka B.P.

The concern here is with the paleobiological, or biobehavioral, changes which took place across this Late Pleistocene transition, with the goal of identifying the significant 
changes in human behavior (as reflected in their biology) during this evolutionary period. The comparative data and analyses have almost all been presented elsewhere, although frequently in either a broader comparative context, a more detailed anatomical framework or individual fossil descriptions. They have not been previously focused in on this specific topic.

The paleontological aspects of concern are organized into contrasts and similarities, or major shifts versus little or no change. These are not the same as simple morphological similarities and contrasts, which may be principally of phylogenetic importance but convey little paleobiological information.

\section{THE CONTRASTS}

The principal paleobiological contrasts which have emerged are those related to aspects of manipulation, mobility patterns and stress levels.

The changes in human manipulative behavior involve both the upper limb and the anterior dentition. In the anterior dentition, there is a clear reduction in the relative size of the anterior teeth. This is evident in reduced size of the mandibular incisors and canines, which relative to their cheek tooth dimensions provide $100 \%$ separation between the two groups (Stefan and Trinkaus, 1998). The metric separation is less complete in the maxillary dentition, but it is associated with a reduction in the frequency of incisor shoveling, including both marginal ridge and lingual tubercle development. Both of these result in less anterior tooth mass to resist attrition. Despite these metric changes, there is an overall reduction in the rate of anterior tooth wear relative to cheek tooth wear. There are still early modern humans with complete attritional loss of the anterior tooth crowns (e.g., Dolní Věstonice 16), similar to Neandertals such as Forbes' Quarry 1 and Shanidar 1, 3, 4 and 5, but in contrast with the Neandertals those early modern humans also exhibit complete loss of the occlusal molar crowns. Yet, the pattern of anterior tooth wear, as indicated by incisor beveling angles, remains similar at least between Neandertals and recent humans, indicating that the differences are ones of degree and not pattern (Ungar et al., 1997).

The upper limbs of these Late Pleistocene humans show only subtle differences in diaphyseal structural robusticity, with primarily the right humeri revealing a subtle decrease in relative strength across the transition (Trinkaus, 2000; Hambücken, 1995; Niewoehner, 2000). However, there are marked decreases in the relative dimensions and/or power arms of certain muscle attachments, of which those for trapezius, the rotator cuff muscles, pectoralis major, biceps brachii, pronator teres, flexor carpi ulnaris, flexor pollicis brevis, opponens pollicis and opponens digiti minimi are the most salient (Trinkaus, 1983, 2000; Vandermeersch, 1991; Villemeur, 1994; Vandermeersch and 
Trinkaus, 1995; Niewoehner, 2000). These are combined with reductions in the digital apical tufts, all indicating a reduction in at least peak load forces, if not in endurance for repetitive activities. In contrast, there is also a shift toward hypertrophy of deltoideus, unknown in Neandertals but apparent in some early modern humans (Hambücken, 1993; Churchill and Smith, 2000).

Such upper limb muscular strength reductions are associated with changes in articular proportions, orientations and shapes indicating shifts towards more glenohumeral rotation, arm loading in an extended position, and use of the hand in precision grip positions (Churchill and Trinkaus, 1990; Churchill et al., 96; Niewoehner, 2000).

Initial Upper Paleolithic Neandertal data are provided by Saint-Césaire 1 and isolated teeth from Arcy-Renne (Leroi-Gourhan, 1958; Vandermeersch, 1984; Trinkaus et al., 1999a; Vandermeersch and Mann, 2001). The anterior dentitions exhibit the morphology, hypertrophy and/or relatively rapid attrition of the Neandertals. The upper limb remains possess the muscular hypertrophy evident in Neandertals. Yet the Saint-Césaire 1 radius is one of the few Neandertals without a medially oriented radial tuberosity, and its humerus exhibits a marked deltoideus crest, similar to that of Vogelherd 3.

In the lower limb, the principal shift is one towards a more anteroposterior reinforcement of the femoral midshaft, with the Neandertals having subcircular diaphyseal cross-sections and those of almost all early modern humans [the exceptions being a couple of the Předmostí femora (Matiegka, 1938)] have marked pilasters which structurally reinforced their diaphyses anteroposteriorly. Among recent humans, such contrasts in femoral diaphyseal shape are associated with differential levels of mobility, independent of overall robusticity levels (Ruff, 2000). The Saint-Césaire 1 femoral diaphysis, although morphologically Neandertal-like, exhibits a pattern of anteroposterior reinforcement which places it within the early modern human range of variation (Trinkaus et al., 1999a).

The Neandertals have also been noted for their high levels of stress indicators, including traumatic injuries and systemic developmental insults (dental enamel hypoplasias) (Ogilvie et al., 1989; Brennan, 1991; Berger and Trinkaus, 1995). Comparable data are not available for earlier Upper Paleolithic early modern humans, but qualitative observations permit several observations. Dental enamel hypoplasias, although present, clearly occur in much lower frequencies than among the Neandertals. Moreover, marked hypoplasias indicating a severe stress episode and its survival, such as those on Dolní Věstonice 15, are present among early modern humans but not the Neandertals. Traumatic lesions occur among early modern humans, but whereas they are ubiquitous among mature Neandertals, they are less common in early modern humans. Yet, the head and upper limb dominant pattern of traumatic lesions seen among the 
Neandertals (Berger and Trinkaus, 1995) appears to occur as well among their temporal successors. Early Upper Paleolithic humans also shows evidence of long-term survival of systemic difficulties (e.g., Cro-Magnon 1, Dolní Věstonice 15, Sunghir 3), yet Neandertal adults survived extended periods of time with serious injuries (e.g., La Chapelle-aux-Saints 1, Shanidar 1) and at least one Neandertal child (Pech-de-l'Azé 1) survived infancy with abnormal cranial growth patterns.

These differences in stress levels, if not patterns, conform to the impression of significantly greater demographic health by at least the Gravettian. Neandertal samples exhibit a dearth of older adults, almost certainly due to a combination of low life expectancy and demographic instability (Trinkaus, 1995). Comparable data are not available for early modern humans, but older adults appear to be more common, especially if differential rates of skeletal and dental degeneration (Skinner, 1997) are taken into account.

Interestingly, stable isotope data, although indicating that the Neandertals were capable hunters of terrestrial mammals (Richards et al., 2000; Bocherens et al., 2001), also indicate that at least by the Gravettian humans were on average better able to exploit low yield resources that would have provided more stable food acquisition (Richards et al., 2001). The Upper Paleolithic Neandertals from Vindija fall in the overlap range between the two samples. These dietary breadth changes, in addition to improvements in many aspects of technology by the Gravettian (Svoboda et al., 1996), would have affected the demographic stabilities of these populations.

\section{THE SIMILARITIES}

At the same time that these paleobiological contrasts are evident, it is increasingly apparent that a series of functional anatomical aspects changed very little if at across the Middle to Upper Paleolithic transition.

These include aspects of endocranial capacity, encephalization and endocranial growth, as well as internal proportions of the endocranial space (Trinkaus and Tompkins, 1990; Ruff et al., 1997; Weaver, 2001). In addition, there are no differences in relative spinal canal proportions (Trinkaus, 1983; Arensburg, 1991; Weaver et al., 2001). Although these features reflect primarily neuroanatomical dimensions and not internal organization, they indicate no apparent differences in neurological capabilities, cerebral or peripheral.

Despite differences in the anterior dentition related to manipulation, there is little difference in either cheek tooth dimensions (Stefan and Trinkaus, 1998) or in the relative hypertrophy of the mandibular corpus once scaled to facial size (Trinkaus, 2000; Dobson and Trinkaus, n.d.). This suggests similar levels of masticatory effort, which is 
predictable given both the overall skeletal gracility of the Neandertal face and its inability to generate high bite forces (Kallfelz-Klemish and Franciscus, n.d.).

Neandertal lower limb remains appear massively built, but once scaled to their hyperarctic body proportions (Holliday, 1997), there is little difference between the Neandertals and any of the Late Pleistocene early modern humans in lower limb robusticity. This applies to their femoral neck-shaft angles (Trinkaus, 1993, 2000), femoral diaphyses (Ruff et al., 1993, 2000; Trinkaus and Ruff, 1999a), femoral curvature (Shackelford and Trinkaus, n.d.), tibial diaphyses (Trinkaus and Ruff, 1999b; Trinkaus et al., 1999b), gluteal tuberosities (Trinkaus, 2000), quadriceps femoris moment arms (Trinkaus and Rhoads, 1999), hallucal phalanges (Trinkaus and Hilton, 1996), and articular proportions (Ruff et al., 1993; Trinkaus, 2000). The one difference is the hypertrophy of their lateral pedal phalanges (Trinkaus and Hilton, 1996; Trinkaus, 2000), which is reduced in the Gravettian human sample; given the stasis in locomotor hypertrophy elsewhere in the foot and leg, it is likely that this is reflecting the advent of supportive footwear reducing traction through the lesser toes.

These aspects of the lower limb indicate that there was little change in the level of movement and/or burden carrying across this Late Pleistocene transition, only subtle differences in the pattern of mobility as indicated above. Indeed, mobility, whether local or long-distance, appears to have remained important throughout the Upper Paleolithic (Holt and Churchill, 2000; Trinkaus et al., 2001), decreasing only with sedentism in the early Holocene (Ruff et al., 2000).

Similarities in the general behavioral patterns are also indicated by three extrasomatic reflections. First, Neandertal populations persisted for several millennia in both south-central Europe and throughout much of Iberia after the appearance of early modern humans in neighboring regions (Hublin et al., 1995; Smith et al., 1999; Zilhão, 2000), indicating their ability to compete ecologically with those early modern human populations. Second, the emergence of an Upper Paleolithic techno-cultural system, either clearly by Neandertals or well before the appearance of Upper Paleolithic early modern humans in the northwestern Old World (and hence by Neandertals by default) (Granger and Lévêque, 1997; Zilhão and d'Errico, 1999; Kuhn et al., 2001) argues for Neandertal cultural abilities similar to those of early Upper Paleolithic early modern humans. And third, the scattered evidence for some significant degree of admixture between Neandertals and early modern humans (Smith and Trinkaus, 1991; Duarte et al., 1999; Bräuer, 2001) indicates that the populations viewed each other as behaviorally, culturally and cognitively similar. 


\section{DISCUSSION}

From this review, it appears that the biobehavioral differences between the Middle Paleolithic Neandertals and the Upper Paleolithic early modern humans are related to manipulative behaviors, the patterns of mobility and overall stress levels. All of these aspects can be related, directly or indirectly, to the major improvements in subsistence and processing technology that define the early phases of the Upper Paleolithic. Reductions in upper limb muscularity and anterior tooth wear, changing patterns of arm and hand use, reduced levels of trauma, increasingly stable food supplies, reduced developmental systemic stress levels, and improved demographic stability can all be related to having the technological (and organizational) ability to acquire sustenance more reliably with less physical effort. Whatever inherited or plastic changes were responsible for these behavioral changes, all of them would have been promoted by the cultural evolutionary changes extensively documented in the Paleolithic archeological record.

In the context of this, the initial Upper Paleolithic Neandertals appear to be largely similar to the Neandertals. Yet, there are suggestions of change, in the humeral deltoideus tuberosity, the radial tuberosity and the femoral midshaft biomechanics, indicating that the biobehavioral shift started within the Neandertals.

Despite the anatomical differences between the Neandertals and modern humans and regardless of how many of them were ultimately ancestral to early modern human populations, the biobehavioral differences between the two groups appear to be closely linked to the abundant cultural changes that were taking place during OIS 3. The result therefore is one of the Neandertals appearing considerably more human than many have considered them to have been, or alternatively, early modern humans becoming less "modern" than we would like them to be.

\section{BIBLIOGRAPHY}

Arensburg (B.) 1991, The vertebral column, thoracic cage and hyoid bone, in $\mathrm{O}$. BarYosef, B. Vandermeersch (eds), Le Squelette Moustérien de Kébara 2, Éditions du C.N.R.S., Paris, p. 113-146.

Berger (T.D.), TrinKaus (E.) 1995, Patterns of trauma among the Neandertals, Journal of Archaeological Science 22: 841-852.

Bocherens (H.), Billiou (D.), MariotTi (A.), Toussaint (M.), Patou-Mathis (M.),
Bonjean (D.), OtTe (M.) 2001, New isotopic evidence for dietary habits of Neandertals from Belgium, Journal of Human Evolution 40: 497-505.

BRÄUER (G.) 2001, The "Out-of-Africa" model and the question of regional continuity, in P.V. Tobias, M.A. Raath, J. Moggi-Cecchi, G.A. Doyle (eds), Humanity from African Naissance to Coming Millennia, Firenze University Press, Florence, p. 183-189. 
Brennan (M.U.) 1991, Health and Disease in the Middle and Upper Paleolithic of Southwestern France: A Bioarcheological Study, Ph. D. thesis, New York University.

Churchill (S.E.), Pearson (O.M.), Grine (F.E.), Trinkaus (E.), Holliday (T.W.) 1996, Morphological affinities of the proximal ulna from Klasies River Mouth Main Site: Archaic or modern? Journal of Human Evolution 31: 213-237.

Churchill (S.E.), SMith (F.H.) 2000, A modern human humerus from the early Aurignacian of Vogelherdhöhle (Stetten, Germany), American Journal of Physical Anthropology 112: 251-273.

Churchill (S.E.), Trinkaus (E.) 1990, Neandertal scapular glenoid morphology, American Journal of Physical Anthropology 83: $147-160$

Dobson (S.D.), Trinkaus (E.) n.d., Crosssectional geometry and morphology of the mandibular symphysis in Middle and Late Pleistocene Homo. Journal of Human Evolution (in review),

Duarte (C.), Maurício (J.), Pettitt (P.B.), Souto (P.), Trinkaus (E.), Van Der Plicht (H.), ZILhão (J.) 1999, The early Upper Paleolithic human skeleton from the Abrigo do Lagar Velho (Portugal) and modern human emergence in Iberia, Proceedings of the National Academy of Science (USA) 96: 7604-7609.

FrAYER (D.W.) 1993, Evolution at the European edge: Neandertal and Upper Paleolithic relationships, Préhistoire Européene 2: 9-69.

Granger (J.M.), LÉVÊQUe (F.) 1997, Parure castelperronienne et aurignacienne : étude de trois séries inédites de dents percées et comparaisons, Comptes rendus de l'Académie des Sciences de Paris 325 : 537-543.

HambüCKen (A.) 1993, Révision des particularités de l'humérus des
Néandertaliens européens, Comptes rendus de l'Académie des Sciences de Paris 317 : 109-114.

HAMbÜCKEN (A.) 1995, Étude du degré de robustesse des os longs du membre supérieur des Néandertaliens, Bulletins et Mémoires de la Société d'Anthropologie de Paris, n.s. 7 : $37-47$

HollidAY (T.W) 1997, Postcranial evidence for cold adaptation in European Neandertals, American Journal of Physical Anthropology 104: 245-258.

Holt (B.), Churchill (S.E.) 2000, Behavioral changes in European Upper Paleolithic foragers: evidence from biomechanical analysis of the appendicular skeleton (abstract), American Journal of Physical Anthropology, Suppl. 30: 182.

Hublin (J.J.) 2000, Modern-nonmodern hominid interactions: A Mediterranean perspective, in O. Bar-Yosef, D. Pilbeam (eds), The Geography of Neandertals and Modern Humans in Europe and the Greater Mediterranean, Peabody Museum, Bulletin 8: 157-182.

Hublin (J.J.), Barroso Ruiz (C.), Medina LaRA (P.), Fontugne (M.), Reyss (J.L.) 1995, The Mousterian site of Zafarraya (Andalucia, Spain): dating and implications on the Palaeolithic peopling process of western Europe, Comptes rendus de l'Académie des Sciences de Paris 321: 931-937.

JORDE (L.B.), BAMSHAD (M.J.), ROGERS (A.R.) 1998, Using mitochondrial and nuclear DNA markers to reconstruct human evolution, Bioessays 20: 126-136.

Kallfelz-Klemish (C.F.), Franciscus (R.G.) n.d., Bite force production capability and efficiency in Neandertals and modern humans, American Journal of Physical Anthropology (in press).

Kuhn (S.L.), Stiner (M.C.), Reese (D.S.), GüLEÇ (E.) 2001, Ornaments of the earliest 
Upper Paleolithic: new insights from the Levant, Proceedings of the National Academy of Sciences (USA) 98: 7641-7646.

LEROI-Gourhan (A.) 1958, Étude des restes humains fossiles provenant des Grottes d'Arcysur-Cure, Annales de Paléontologie 44: 87-146.

MatiegKa (J.) 1938, Homo Predmostensis, Folsilní člověk z Předmostí na Moravě II, Česká Prague, Akademie Věd a Umění.

NiEWOEHNER (W.A.) 2000, The Functional Anatomy of Late Pleistocene and Recent Human Carpometacarpal and Metacarpophalangeal Articulations, Ph. D. thesis, University of New Mexico.

NoRDBORG (M.) 1998, On the probability of Neanderthal ancestry, American Journal of Human Genetics 63: 1237-1240.

Ogilvie (M.D.), Curran (B.K.), TrinKaus (E.) 1989, The incidence and patterning of dental enamel hypoplasias among the Neandertals, American Journal of Physical Anthropology 79: 25- 41.

RELETHFORD (J.H.) 2001, Genetics and the Search for Modern Human Origins, WileyLiss, New York.

Richards (M.P.), Pettitt (P.B.), Stiner (M.C.), Trinkaus (E.) 2001, Stable isotope evidence for increasing dietary breadth in the European mid-Upper Paleolithic, Proceedings of the National Academy of Science (USA) 98: 6528-6532.

Richards (M.P.), PetTitT (P.B.), Trinkaus (E.), Smith (F.H.), Paunović (M.), Karavanić (I.) 2000, Neanderthal diet at Vindija and Neanderthal predation: The evidence from stable isotopes, Proceedings of the National Academy of Science (USA) 97: 7663-7666.

RuFF (C.B.) 2000, Biomechanical analysis of archaeological human skeletons, in M.A. Katzenberg, S.R. Saunders (eds), Biological Anthropology of the Human Skeleton, WileyLiss, New York, p. 71-102.
Ruff (C.B.), Trinkaus (E.), HollidaY (T.W.) 1997, Body mass and encephalization in Pleistocene, Homo. Nature 387: 173-176.

Ruff (C.B.), Trinkaus (E.), Holt (B.) 2000, Lifeway changes as shown by postcranial skeletal robustness (abstract), American Journal of Physical Anthropology, Suppl. 30: 266.

Ruff (C.B.), Trinkaus (E.), Walker (A.) LARSEN (C.S.) 1993, Postcranial robusticity in Homo, I: Temporal trends and mechanical interprétations, American Journal of Physical Anthropology 91: 21-53.

ShaCKElFord (L.L.), TrinKaus (E.) (in press), Late Pleistocene human femoral diaphyseal anterior curvature, American Journal of Physical Anthropology (in review).

SKINNER (M.) 1997, Dental wear in immature Late Pleistocene European hominines, Journal of Archaeological Science 24: 677-700.

SMith (F.H.) 1994, Samples, species, and speculations in the study of modern human origins, in M.H. Nitecki, D.V. Nitecki (eds), Origins of Anatomically Modern Humans, Plenum, New York, p. 227-249.

SMith (F.H.), Trinkaus (E.) 1991, Les origines de l'homme moderne en Europe centrale : Un cas de continuité, in J.-J. Hublin, A.-M. Tillier (éds), Aux Origines d'Homo sapiens, Nouvelle Encyclopédie Diderot, Presses Universitaires de France, Paris, p. 251-290.

Smith (F.H.), Trinkaus (E.), Pettitt (P.B.), Karavanić (I.), Paunović (M.) 1999, Direct radiocarbon dates for Vindija $G_{1}$ and Velika Pećina Late Pleistocene hominid remains, Proceedings of the National Academy of Science (USA) 96: 12281-12286.

Stefan (V.H.), Trinkaus (E.) 1998, Discrete trait and dental morphometric affinities of the Tabun 2 mandible, Journal of Human Evolution 34: 443-468. 
StRINGER (C.B.) 1994, Out of Africa-A personal history, in M.H. Nitecki, D.V. Nitecki (eds), Origins of Anatomically Modern Humans, Plenum, New York, p. $149-172$

Svoboda (J.), LožEK (V.), VlČEK (E.) 1996, Hunters between East and West, Plenum, New York-London.

Trinkaus (E.) 1983, The Shanidar Neandertals, New York, Academic Press.

TrinKAUs (E.) 1993, Femoral neck-shaft angles of the Qafzeh-Skhul early modern humans, and activity levels among immature Near Eastern Middle Paleolithic hominids, Journal of Human Evolution 25: 393-416.

TrinKaus (E.) 1995, Neanderthal mortality patterns, Journal of Archaeological Science 22: 121-142.

TrinKaus (E.) 2000, The "Robusticity Transition" revisited, in C. Stringer, R.N.E. Barton, C. Finlayson (eds), Neanderthals on the Edge, Oxbow Books, Oxford, p. 227-236.

Trinkaus (E.), Churchill (S.E.), Ruff (C.B.), VANDERMEERSCH (B.) 1999a, Long bone shaft robusticity and body proportions of the SaintCésaire 1 Chatelperronian Neandertal, Journal of Archaeological Science 26: 753-773.

Trinkaus (E.), Formicola (V.), Svoboda (J.), Hillson (S.W.), HollidaY (T.W.) 2001, Dolní Věstonice 15: Pathology and persistence in the Pavlovian, Journal of Archaeological Science 28: 1291-1308.

Trinkaus (E.), Hilton (C.E.) 1996, Neandertal pedal proximal phalanges: diaphyseal loading patterns, Journal of Human Evolution 30: 399-425.

TRINKAUS (E.), RHOADS (M.L.) 1999, Neandertal knees: power lifters in the Pleistocene? Journal of Human Evolution 37: 833-859.

Trinkaus (E.), RuFF (C.B.) 1999a, Diaphyseal cross-sectional geometry of Near Eastern
Middle Paleolithic humans: The femur, Journal of Archaeological Science 26: 409-424.

Trinkaus (E.), RufF (C.B.) 1999b, Diaphyseal cross-sectional geometry of Near Eastern Middle Paleolithic humans: The tibia, Journal of Archaeological Science 26: 1289-1300.

Trinkaus (E.), Stringer (C.B.), Ruff (C.B.), Hennessy (R.J.), Roberts (M.B.), Parfitt (S.A.) 1999, Diaphyseal cross-sectional geometry of the Boxgrove 1 Middle Pleistocene human tibia, Journal of Human Evolution 37: 1-25.

Trinkaus (E.), Tompkins (R.L.) 1990, The Neandertal life cycle: The possibility, probability, and perceptibility of contrasts with recent humans, in C.J. DeRousseau (ed.), Primate Life History and Evolution. Monographs in Primatology 14, Wiley-Liss, New York, p. 153-180.

Ungar (P.S.), FenNell (K.J.), GoRdon (K.), TrinKaUs (E.) 1997, Neandertal incisor beveling, Journal of Human Evolution 32: 407-421.

VANDERMEERSCH (B.) 1984, À propos de la découverte du squelette Néandertalien de Saint-Césaire, Bulletins et Mémoires de la Société d'Anthropologie de Paris, Série XIV, 1: 191-196.

VANDERMEERSCH (B.) 1991, La ceinture scapulaire et les membres supérieures, in O. Bar-Yosef, B. Vandermeersch (éds), Le Squelette Moustérien de Kébara 2, Éditions du C.N.R.S, Paris, p. 157-178.

VANDERMEERSCH (B.) 1995, Homo sapiens sapiens : ce que disent les fossiles, $L a$ Recherche 26 (277) : 614-620.

VANDERMEersch (B.), MANN (A.E.) 2001, The dentition of Saint-Césaire 1, a partial skeleton from the Châtelperronian levels of La Roche à Pierrot (Charente-Maritime) (abstract), American Journal of Physical Anthropology, Suppl. 32: 154-155. 
VANDERMEersCH (B.), TrinKaus (E.) 1995, The postcranial remains of the Régourdou 1 Neandertal: The shoulder and arm remains, Journal of Human Evolution 28: 439-476.

VILLEMEUR (I.) 1994, La Main des Néandertaliens, C.N.R.S. Éditions, Paris.

WALl (J.D.) 2000, Detecting ancient admixture in humans using sequence polymorphism data, Genetics 154: 1271-1279.

WeAver (A.H.) 2001, The Cerebellum and Cognitive Evolution in Pliocene and Pleistocene Hominids, Ph. D. thesis, University of New Mexico.

Weaver (A.H.), Holliday (T.W.), RufF (C.B.), Trinkaus (E.) 2001, The fossil evidence for the evolution of human intelligences in Pleistocene Homo, in A. Nowell (ed.), In the Mind's Eye: Multidisciplinary Perspectives on the Evolution of Human Cognition, International Monographs in Prehistory, Ann Arbor, p. 154-172.

Wolpoff (M.H.), HaWKS (J.), FraYeR (D.W.), HunLEY (K.) 2001, Modern human ancestry at the peripheries: A test of the replacement theory, Science 291: 293-297.

ZILHÃo (J.) 2000, The Ebro frontier: a model for the late extinction of Iberian Neanderthals, in C.B. Stringer, R.N.E. Barton, J.C. Finlayson (eds), Neanderthals on the Edge, Oxbow Books, Oxford, p. 111-121.

ZILHÃo (J.), D’ERrico (F.) 1999, The chronology and taphonomy of the earliest Aurignacian and its implications for the understanding of Neandertal extinction, Journal of World Prehistory 13: 1-68. 